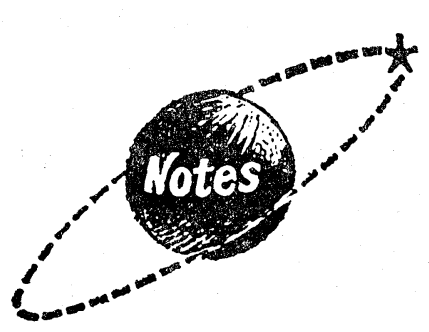

炭化水素燃焼の

立体図形表示に関する一注解

-1982. 11. 26 受理一

小山工業高等専門学校 代 淳吉朗

\section{1. 緒 言}

前各報122)に㧅いて縮少または割愛を余儀なくされ た部分のうら，注釈あるいは補足の必要が感じられる 事項のいくつかについて, より適正化の面から考察を 加えてみることとした。今回は燃燒ガス中の未燃ガス, 水蒸気各含有率ならびに 湿り度の影響を主体に述べ る。

\section{2. ガス含有率}

\section{1 未燃ガス}

（I 報の未燃ガス 含有率を必要上, 次のように分 割, 検討した。

$$
\begin{aligned}
& \text { 方式 } \mathrm{A}:[\mathrm{CO}]_{\mathrm{v}}=2(1-\mathrm{x}) / \mathrm{a} \quad[-] \cdots \cdots \cdot \cdots(1) \\
& {\left[\mathrm{H}_{2}\right]_{\mathrm{v}}=\varphi(1-\mathrm{y}) / \mathrm{a} \quad[-] \cdots \cdots \cdot \cdots(2)} \\
& {\left[\mathrm{CO}^{\prime}\right]_{\mathrm{v}}=2(1-\mathrm{x}) / \mathrm{a}^{\prime} \quad[-] \cdots \cdots \cdot \cdots(3)} \\
& {\left[\mathrm{H}_{2}{ }^{\prime}\right]_{\mathrm{v}}=\varphi(1-\mathrm{y}) / \mathrm{a}^{\prime} \quad[-]_{\cdots} \cdot \cdots \cdot \cdots(4)} \\
& \text { 方式 } \mathrm{B}:(\mathrm{CO})_{\nabla}=2(1-\mathrm{x}) / \mathrm{b} \quad[-] \cdots \cdots \cdots \cdot(5) \\
& \left(\mathrm{H}_{2}\right)_{\mathrm{v}}=\varphi(1-\mathrm{y}) / \mathrm{b} \quad[-] \cdots \cdots \cdots \cdot(6) \\
& \left(\mathrm{CO}^{\prime}\right)_{\mathrm{v}}=2(1-\mathrm{x}) / \mathrm{b}^{\prime} \quad[-] \cdots \cdots \cdot \cdot(7) \\
& \left(\mathrm{H}_{2}{ }^{\prime}\right)_{\mathrm{v}}=\varphi(1-\mathrm{y}) / \mathrm{b}^{\prime} \quad[-] \cdots \cdots \cdot(8)
\end{aligned}
$$

これらを図示したのがFig.1〜4で（Ｉ）の Fig.12～14に 対応する。ここでは新たに $\varphi=4$ を取り上げた。な和 方式 Bの乾きガスのものは湿りガスのものと類似の形

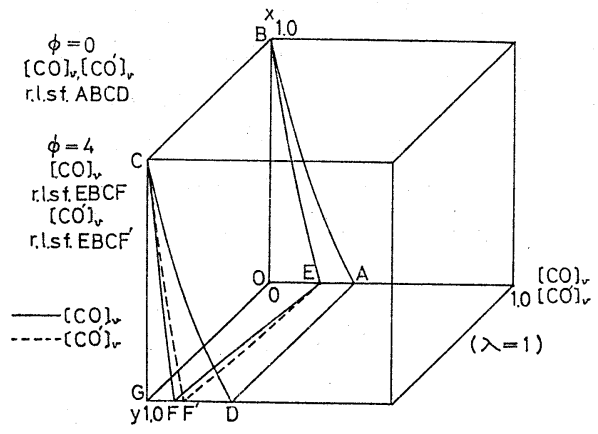

Fig. 1 CO content surface for method "A"

機械工学科 栃木県小山市中久喜771

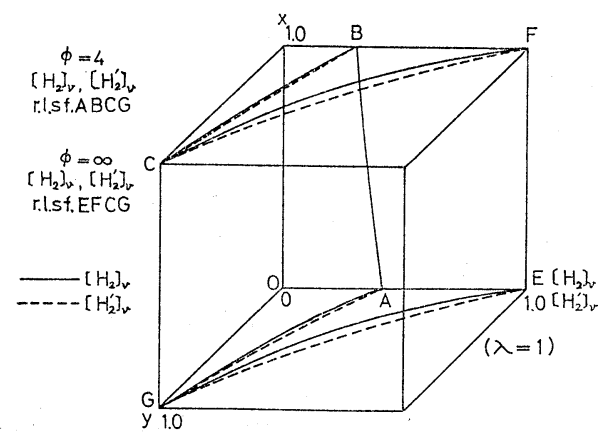

Fig. $2 \mathrm{H}_{2}$ content surface for method "A"

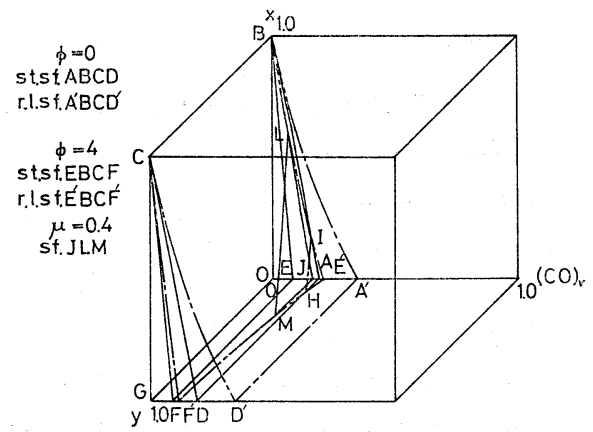

Fig. 3 CO content surface for wet products in method " $B$ "

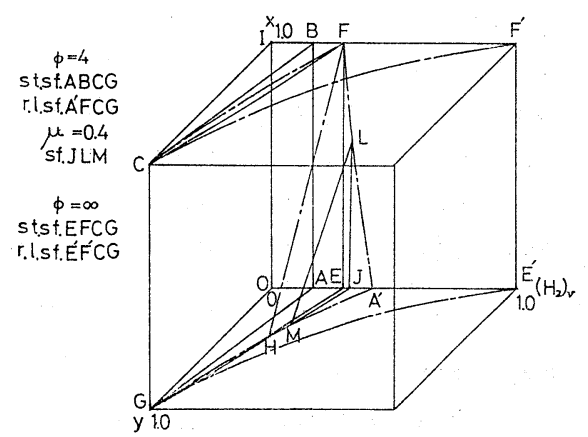

Fig. $4 \mathrm{H}_{2}$ content surface for wet products in method "B" 


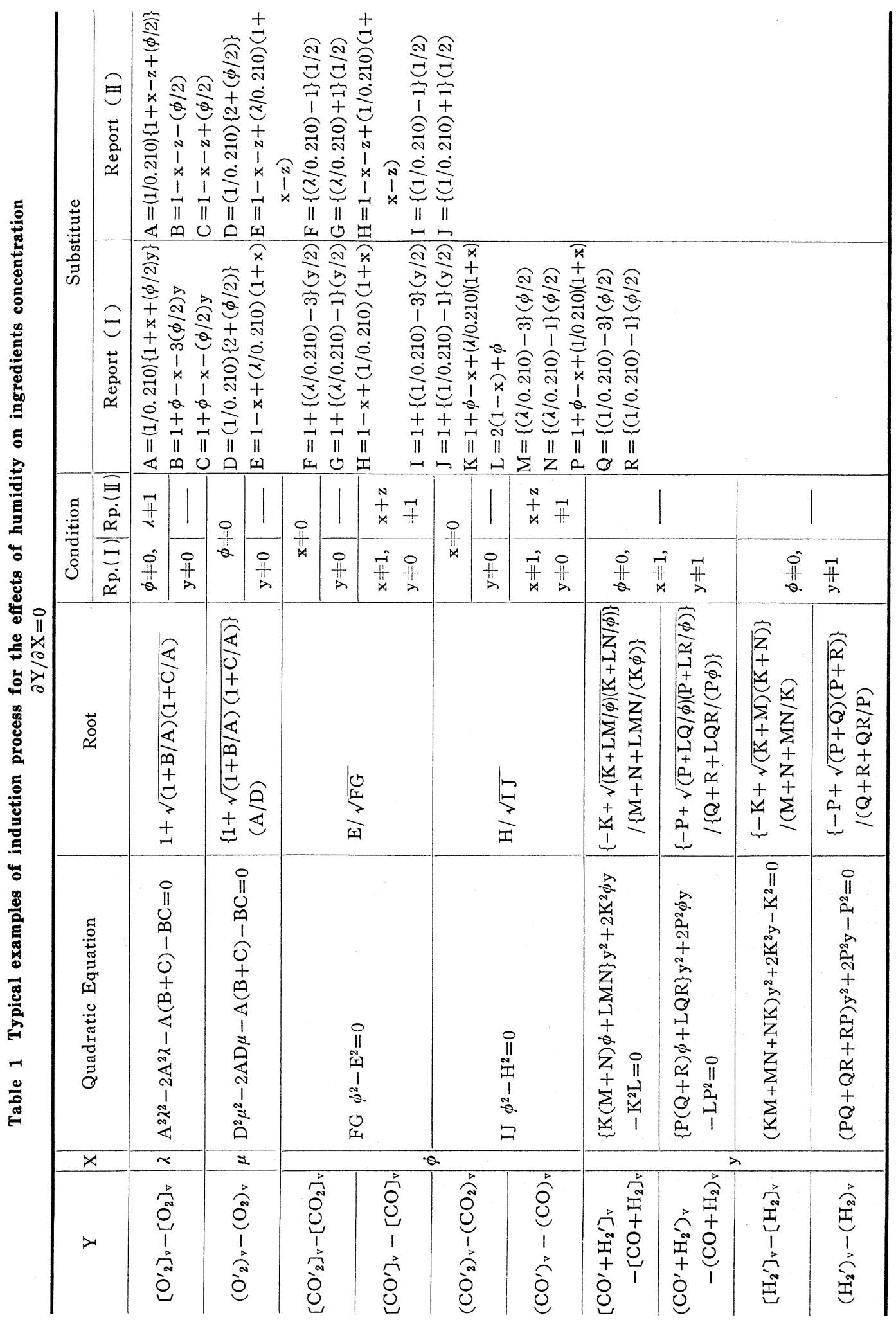


状となるため省略した。図で $\varphi$ が同一の場合，湿り， 乾き各曲面は $\mathrm{x}-\mathrm{CO}^{* 1}, \mathrm{x}-\mathrm{H}_{2}{ }^{* 2}$ 平面上で一致する。 全般に各曲面は入または $\mu$ の増加につれ, Fig.1, 3 の 辺 B C, Fig.2, 4 の辺 C Gを軸に低限曲面である $\mathrm{x}$ $\mathrm{y}$ 平面に近付き,一方高限曲面は方式に無関係であり, またすべての曲面は完全燃焼線上で合致し，あるいは

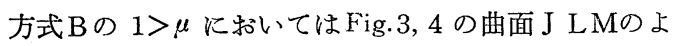
らに $\mathrm{x}, \mathrm{y}$ 上限が制約されるなど前報の性質がそのま ま適用できる。ただしこの場合, 特有曲線や曲面は存 在しないが, 方式 Bに拈いては $\varphi_{1}$ の基準曲面と $\varphi_{2}$ の 高限曲面とがガスの湿り, 乾きに関係なく次の条件を 満足するとき交叉することがわかった。

C O の場合： $\quad 1+0.710 \varphi_{1} \geqq 0.210 \varphi_{2}$

$\mathrm{H}_{2}, \mathrm{H}_{2} \mathrm{O}$ の場合 : $\varphi_{1} \varphi_{2} \geqq 2.420 \varphi_{1}-4.420 \varphi_{2} \cdots \cdots$...(10) この例が Fig.3, 4 のIH, F Hで示される。

\section{2 水蒸気}

参考のためガス中の水蒸気含有率を考えると，

$$
\begin{array}{rlrl}
\text { 方式 } \mathrm{A}: & {\left[\mathrm{H}_{2} \mathrm{O}\right]_{\mathrm{v}}} & =\varphi \mathrm{y} / \mathrm{a} & {[-] \cdots \cdots \cdots \cdots \cdots(11)} \\
{\left[\mathrm{H}_{2} \mathrm{O}\right]_{\mathrm{v}}} & =\varphi / \mathrm{a}_{2}{ }^{* 3} & {[-] \cdots \cdots \cdots \cdots \cdots(12)} \\
\text { 方式 } \mathrm{B}:\left(\mathrm{H}_{2} \mathrm{O}\right)_{\mathrm{v}}=\varphi \mathrm{y} / \mathrm{b} & {[-] \cdots \cdots \cdots \cdots \cdots \cdot(13)} \\
\left(\mathrm{H}_{2} \mathrm{O}\right)_{\mathrm{v}} & =\varphi / \mathrm{b}_{2} * 4 & {[-] \cdots \cdots \cdots \cdots \cdots \cdots(14)}
\end{array}
$$

これらについて高限, 基準各曲面を図示したのが Fig. 5,6 である。一般に各曲 (平) 面はすべて $\lambda, \mu$ の増大に つれ低限曲面である $\mathrm{x}-\mathrm{y}$ または $\mathrm{x}-\mathrm{z}$ 平面に近接す る。これはFig.5 と和いては辺OBを軸に回転する形 をとる。ここでも高限曲面は方式に左右されない一 方, 方式Bに秃いてはこれと基準曲面とが完全然焼線 上で一致し, $1>\mu$ の場合, Fig. 5, 6 の OJK, IJH の ようにx, y の上限が制限されるなど, 今をでの事項 がそのままあてはまってくる。また前項と同様この場

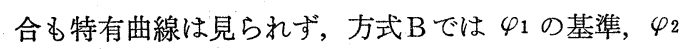
の高限各曲面が式(10)の状態において交叉を起こす。

\section{3. 湿り度の影響}

湿り度の各成分ガス含有率に与える影響の 数值解法の具体例を Table 1 亿示す。変量X についてはすべてを網羅3つしなければならな いが，さしあたり計算が容易のもののみに限 定した。本表では両方式とも同型, また $\mathrm{CO}_{2}$, $\mathrm{CO}$ ののは一括できることが示されてい る。

\footnotetext{
$*_{1}[\mathrm{CO}]_{\mathrm{v}},\left[\mathrm{CO}^{\prime}\right]_{\mathrm{v}},(\mathrm{CO})_{\mathrm{v}},\left(\mathrm{CO}^{\prime}\right)_{\mathrm{v}}$ 括表示

*2 $\left[\mathrm{H}_{2}\right]_{\mathrm{v}},\left[\mathrm{H}_{2}^{\prime}\right]_{\mathrm{v}},\left(\mathrm{H}_{2}\right)_{\mathrm{v}},\left(\mathrm{H}_{2}{ }^{\prime}\right)_{\mathrm{v}}$ を一括 表示

*3（II)報に扮ける aを表わす。

*4（II）報に括ける bを表わす。
}

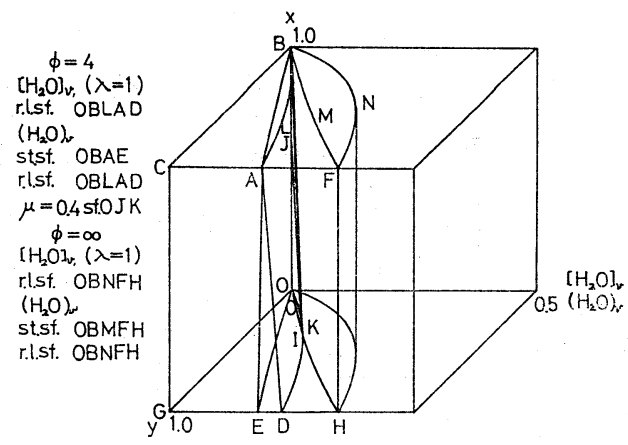

Fig. $5 \mathrm{H}_{2} \mathrm{O}$ content surface in the Report (I)

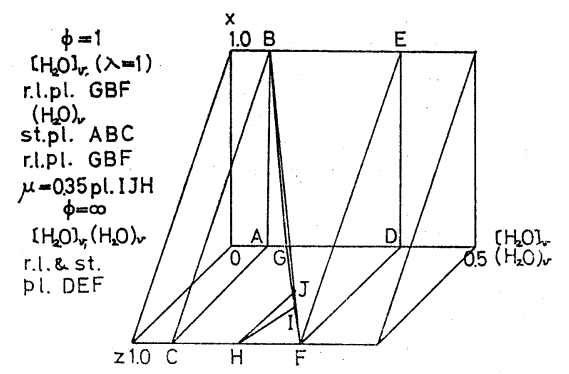

Fig. $6 \mathrm{H}_{2} \mathrm{O}$ content plane in the Report (II)

\section{4. 計算図表}

（I）報の式(37) とよる 00 の計算図表を Fig.7 亿示す。 $\mathrm{CO}_{2}, \mathrm{CO}, \mathrm{H}_{2}, \mathrm{~N}_{2}$ の各含有率值を点 $\mathrm{A}, \mathrm{B}, \mathrm{C}, \mathrm{D}$ と 乙, 線分 $\mathrm{A} \mathrm{B}, \mathrm{CD}$ と a, b 各尺との交点を $\mathrm{E}, \mathrm{F}$, 線分 $\mathrm{EF}$ と $\mathrm{c}$ 尺との交点を $\mathrm{G}$ すれば， $\mathrm{m} の$ 值 $\mathrm{H}$ と $\mathrm{G}$ との 延長が $\ell 0$ 尺と交わる点 Iが求めるものとなる。

\section{5. 結 言}

（1）未燃ガス含有率をそれぞれ分割しても，一般性 質はそのまま引き継がれる。この場合特有曲線や曲面 は現われず比較的単純な形態を示す。ただし方式 Bで はある範囲内で $\varphi$ の異なる基準, 高限各曲面が交叉す

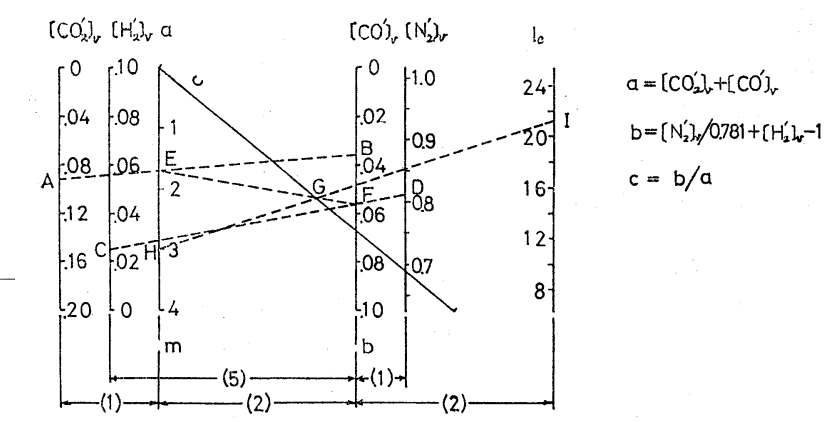

Fig. 7 Nomogram of $\ell 0$ 
る。(2) 水蒸気含有率も一般性能は前記未燃ガスのも のとほぼ同様といえる。(3) 方式Aの表示運用両面で の有効性がさらに確認された。(4) 湿り度の影響は系 統別に整理することができる。

文献

1）代 淳吉朗，燃協誌，59，（642），849（1980）
2）代 淳吉朗，燃協誌，60，(646)，95 (1981)

3）たとえば Wylie, C.R.Jr., Calculus (Mc Graw -Hill) p. 395 (1953)

富久泰明 訳, 微分積分学 下(ブレイン図書) p. 482 (1977)

\title{
A Comment on Representation in Solid Figure for Combustion of the Hydrocarbon Fuel
}

\author{
Junkichiro DAI
}

\section{(Oyama National College of Technology)}

SYNOPSIS : - The treatment of the unburned gas with combustion products are considered separately in developing relations between the carbon monoxide and hydrogen. In addition to the ingredients in the previous study the concentration of water vapour with wet combustion products is considered in this paper.

Since the general characteristic of these ingredients content surface are nearly the same as those of previous reports. Another notable feature of figures is that the presence of particular curve and surface has never been firmly established. However, stoichiometric surface of $\varphi_{1}$ and rich limit surface of $\varphi_{2}$ intersect on the condition that equations (9) or (10) is satisfied.

The humidity which affects the ingredients concentration may be well explained in the nature of induction process as shown by Table 1 .

It seems to me that, in comparison with method " $\mathrm{B}$ ", method " $\mathrm{A}$ " has the advantage of simplyfying or convenience for expression and treatment.

\section{Key Words}

Combustion, Hydrocarbon fuel, Solid figure expression, Performance surface, Alignment chart 